\title{
Comparative Analysis of RC Irregular Buildings Designed According to Different Seismic Design Codes
}

\author{
Jaime Landingin ${ }^{1}$, Hugo Rodrigues ${ }^{1}$, Humberto Varum $^{1, *}$, António Arêde ${ }^{2}$ and Aníbal Costa ${ }^{1}$ \\ ${ }^{I}$ Department of Civil Engineering, University of Aveiro, Portugal; \\ ${ }^{2}$ Department of Civil Engineering, University of Porto, Portugal
}

\begin{abstract}
The present paper presents a comparison of seismic provisions of three seismic design codes, the Philippine code, Eurocode 8 and the American code, to the most common ordinary residential frames of standard occupancy. Regular and irregular reinforced concrete frames were analyzed and compared for four storey building types. The response spectrum and the seismic parameters of NSCP 2010 were considered for the horizontal load action with different load combinations. Response spectrum analysis and equivalent lateral force analysis were performed using SAP2000 software package. Five representative columns for each RC frame structure were analyzed. Based on the results of column axial load - bending moment interaction diagrams, EC8 was found to be conservative when compared to NSCP 2010 and 2009 IBC. The conclusion is that for the design and analysis of ordinary RC residential buildings with certain irregularity, EC 8 provisions were considered to be safer.
\end{abstract}

Keywords: Seismic design, building codes, reinforced concrete frame structure, RC column design, interaction diagrams.

\section{INTRODUCTION}

Earthquakes occurring recently in highly populated zones have shown that existing buildings constructed without appropriate seismic resisting characteristics constitute one of the main sources of risks and are the cause of most of the casualties [1]. The interest in gaining better understanding of the seismic behaviour of reinforced concrete (RC) building structures has grown in the past two decades. Damage reports on past earthquakes have indicated that one major cause of failure in RC framed structures is the torsional response of the buildings, induced by the earthquake and/or by the structural irregularities and characteristics. Seismic provisions typically specify criteria for the design and construction of new structures subjected to earthquake ground motions with three goals: (i) minimize the hazard to life associated to all types of structures, (ii) increase the expected performance of structures having a substantial public hazard due to the specific occupancy or use, and (iii) improve the capability of essential facilities to operate after an earthquake [2]. Provisions and assumptions for the design of $\mathrm{RC}$ frames with structural irregularity appear in the majority of the international standards for concrete buildings design. Recently enforced seismic codes, such as NSCP 2010, Eurocode 8, and 2009 IBC have motivated several research activities in each regional seismic code.

This paper, firstly, presents a review of the following international standards evolution. The chosen standards are the National Structural Code of the Philippines (NSCP), European code 8 (EC8), International Building Code (IBC). Secondly, a comparative analysis was performed in terms of

*Address correspondence to this author at the Department of Civil Engineering, University of Aveiro, Portugal; Tel: +351-234-370938;

E-mail: hvarum@ua.pt base shear, storey shear profile and reinforcement requirements in the representative columns for the regular and irregular RC structures.

\section{SEISMIC STANDARD EVOLUTION}

\subsection{National Structural Code of the Philippines}

The National Structural Code of the Philippines (NSCP) has been the primary design code that provides guidance to civil and structural engineers on the design and evaluation of buildings, and any other structures since its $1^{\text {st }}$ edition in 1972. Table 1 shows the brief history of the NSCP [3].

Table 1. Selected Events in the History of Building Codes in the Philippines

\begin{tabular}{|c|c|}
\hline Edition & Official title \\
\hline \hline $\mathbf{1}^{\text {st }}$ & National Structural Code of Buildings (NSCB1972) \\
\hline $\mathbf{2}^{\text {nd }}$ & National Structural Code of Buildings (NSCB 1981) \\
\hline $\mathbf{3}^{\text {rd }}$ & National Structural Code of Buildings (NSCB 1987) \\
\hline $\mathbf{4}^{\text {th }}$ & National Structural Code of the Philippines (NSCP 1992) \\
\hline $\mathbf{5}^{\text {th }}$ & National Structural Code of the Philippines (NSCP 2001) \\
\hline $\mathbf{6}^{\text {th }}$ & National structural Code of the Philippines (NSCP 2010) \\
\hline
\end{tabular}

The latest edition of the NSCP has been historically based on the Uniform Building Code (UBC, 1997) of the USA. Furthermore, UBC-1997 was the first building code that included seismic design provisions which were significantly based on seismic data collected in the early 1990's. The code specifies that the design response spectrum to be used in the analysis was based on factors such as soil profile 
and seismic zone based on fault proximity. The NSCP 2010 adopted the provisions of UBC for earthquake loadings and made 2009 IBC and ACI318-08M as a reference [3].

\subsection{Eurocode}

In Europe, Eurocodes started in 1975, as a result of the decision of the Commission of the European Community to embark on an action programme in the field of construction based on Article 95 of the Treaty of Rome. The objective of the programme was the elimination of technical obstacles to trade and the harmonisation of technical specifications by means of technical rules which, in the first stage, would serve as an alternative to the national rules in force in the Member States and, ultimately, would replace them [4].

In 2006, the publication of EN Eurocodes was concluded. The implementation programme enters the coexistence period, during which the EN Eurocodes are used in parallel with National Standards that have the same scope. Finally in 2010 a full implementation of the code was enforced by withdrawing all conflicting National Standards. It is also mandatory that the Member States accept designs to the EN Eurocodes, since the National standards implementing the EN Eurocodes become the standard technical specification in all contracts for public works and public services. Specifically Eurocode 2 and Eurocode 8 are devoted for concrete and earthquake provisions. Eurocode 2 covers the design of buildings and civil engineering works constructed in plain, reinforced, prestressed and precast concrete while Eurocode 8 explains how to design and analyze building and civil engineering structures resistant to earthquakes [4].

The vast majority of buildings, in earthquake prone areas in Europe, constructed before the 1980's are seismic deficient in terms of our current understanding and knowledge. Furthermore, a significant number of existing RC building structures were constructed before the $70^{\prime}$ s, with plain reinforcing bars, prior to the enforcement of the modern seismicoriented design philosophies [5]. In fact, in some European countries until the 1960 's no specific seismic design provisions were included in building codes and, from that period on, only seismic equivalent lateral loading were considered in building design. Provisions for the design and detailing of members and structures resembling those of modern codes only appeared in European national codes in the 1980's (e.g., Portuguese design code - RSA; European design code Eurocode 8 [6].

The recent earthquakes in Europe (e.g. Bucharest, Romania, 1977; Montenegro, Yugoslavia, 1979; Azores, Portugal, 1980; Campania, Italy, 1980; Kalamata, Greece, 1986; Umbria/Marche, Italy, 1997; Azores, Portugal, 1998; Kocaeli, Turkey, 1999; Athens, Greece, 1999; Molise, Italy, 2002 and 2009; Spain, 2011) confirm and highlight that also Europe may suffer from the vulnerability of the existing building stock [1]. Majority of the countries mention adopted and implemented European Standards in the design and analysis of their structures.

\subsection{International Building Code}

The earliest model code in the United States was the $\mathrm{Na}$ tional Building Code recommended by the National Board of Fire Underwriters, published in 1905 in response to fire insurance losses in the Great Baltimore Fire of 1904. Further- more in 1927, the Pacific Coast Building Officials promulgated the Pacific Coast Building Code, which later became the Uniform Building Code (UBC). The organization of this code differed from that of the National Building Code in that it ranked occupancies by life risk and linked fire safety criteria to specific occupancies. The code included provisions for existing and control of material finishing. In addition, this code contained numerous structural provisions organized by building material type [7].

The Uniform Building Code was widely used west of the Mississippi River until the adoption of the International Building Code in 2000. The National Building Code was promulgated by the insurance industry. It was the basis for most local and state codes until late in the last century [8]. To date UBC is also the model or reference code for many developing countries around the world.

The Southern Building Code, later the Southern Standard Building Code (SBC), was first published by the Southern Building Code Congress in 1945. The Basic Building Code, published by the Building Officials of America (now the Building Officials and Code Administrators International) (BOCA), was first published in 1950. It served the Midwest and New England regions. BOCA later obtained the right to use the title National Building Code. Some editions of the code are called the BOCA/National Building Code. These organizations that published the three model codes were membership organizations with members from the building industry, the building regulatory community, and the public. The model building codes were updated on a three-year cycle [8].

Beginning in the late 1980s, efforts were made to improve consistency and uniformity among the three model codes. By 1990, agreement was reached on consistent chapter organization in the codes, on reasonably consistent occupancy definitions, and on construction types. The three model codes namely, BOCA, Southern Building Code Congress International (SBCCI), and the International Conference of Building Officials (ICBO) agreed to form the International Code Council and to publish one national model code. This resulted in the publication of the 2000 edition of the International Building Code. The International Building Code (IBC) is updated on a three-year cycle and the latest publication was IBC 2012 [9].

\section{MODELLING OF REINFORCED CONCRETE (RC) CONCRETE FRAMED STRUCTURES}

\subsection{Brief Description of the Reinforced Concrete Framed Structures}

$\mathrm{RC}$ residential building of $15 \mathrm{~m} \times 16 \mathrm{~m}$ in plan has been considered for the comparison, as shown in Figs. (1 and 2) (typical floor plan). Four types of RC buildings were used in this study namely:

i) 4 - storey regular frame analyse using response spectrum analysis (RSA),

ii) 4 - storey irregular frame (with shear wall) analyse using equivalent lateral force method (ELFM),

iii) 4 - storey regular frame analyse using equivalent lateral force method (ELFM) and 


\section{Regular RC Frame}

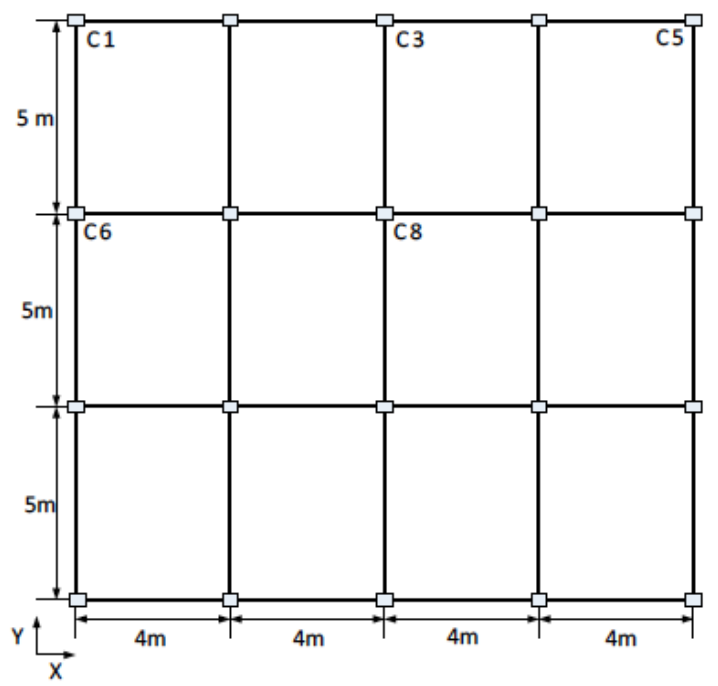

\section{Irregular RC Frame}

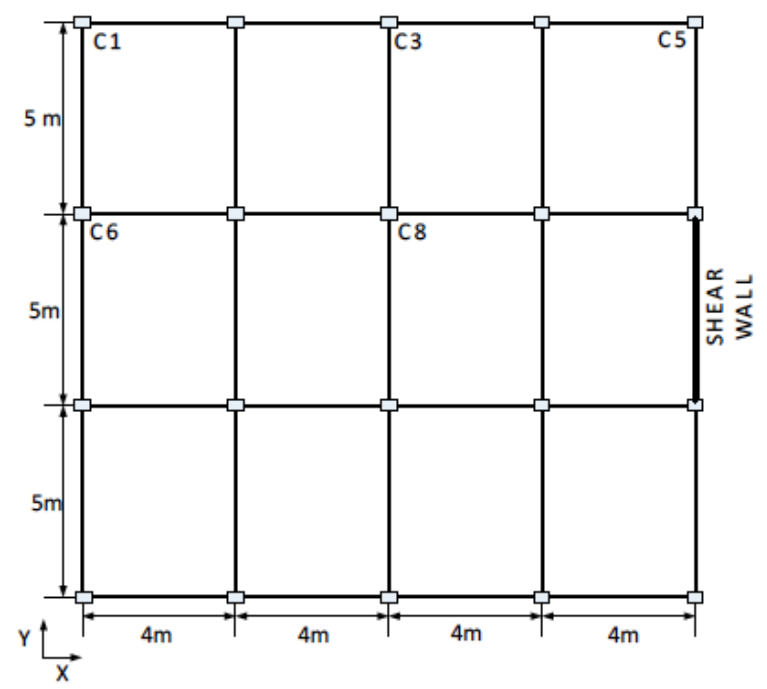

Fig. (1). Typical floor plan for 4 storey regular and irregular RC frame.
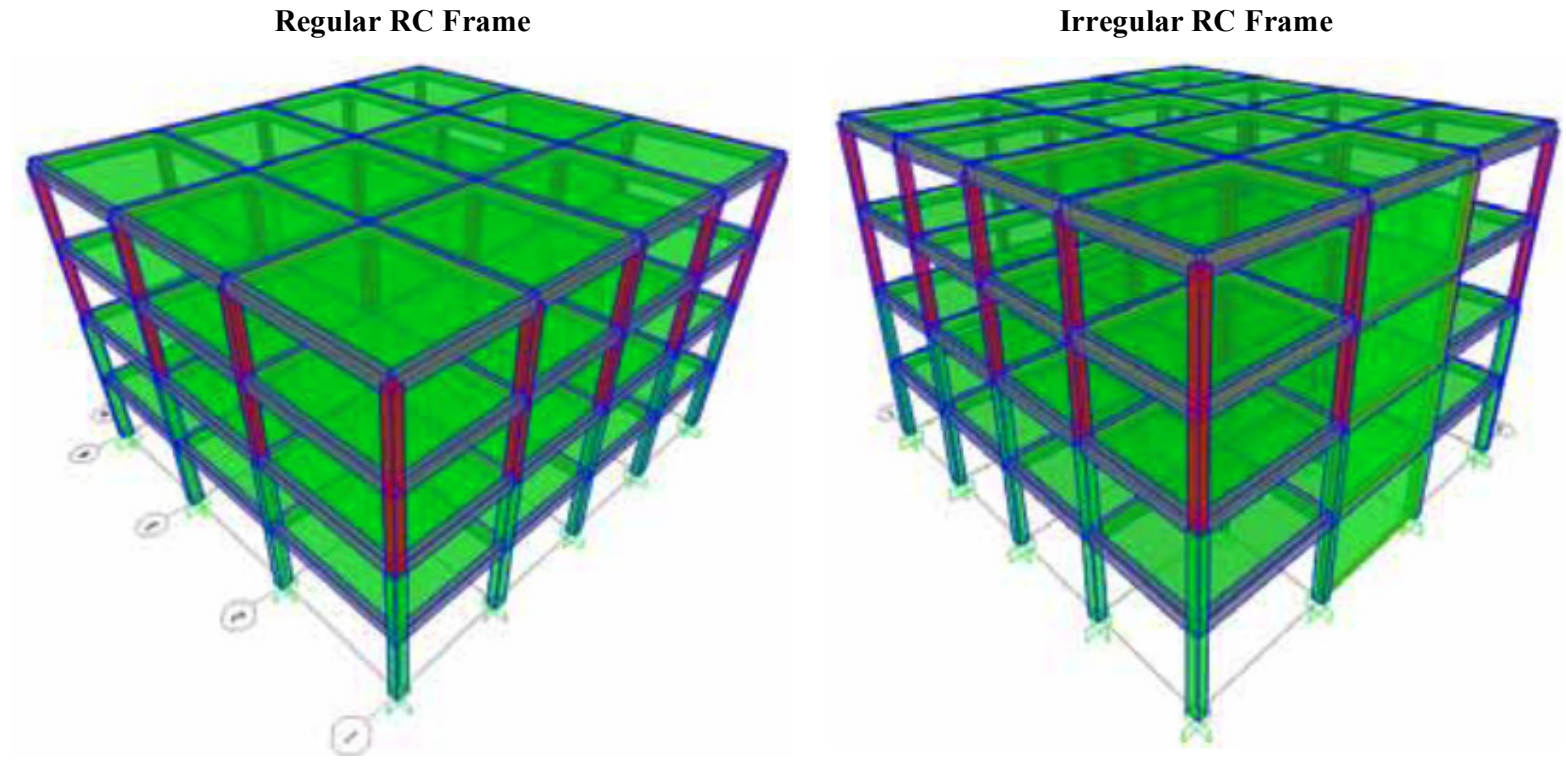

Fig. (2). Tri-dimensional model of 4 storey regular and irregular RC building framed structure.

iv) 4 - storey irregular frame (with shear wall) analyse using response spectrum analysis (RSA).

The RC building has a storey height of $3 \mathrm{~m}$. Dead-load and live-load are $2.5 \mathrm{kN} / \mathrm{m}^{2}$ and $2.0 \mathrm{kN} / \mathrm{m}^{2}$, respectively. The material properties used are: $f^{\prime} c=20 M P \alpha$ for concrete and $f_{v}=400 M P \alpha$ for reinforcement. The member sizes were: $300 \mathrm{~mm} \times 400 \mathrm{~mm}$ column (ground floor to second floor), $300 \mathrm{~mm}$ x $300 \mathrm{~mm}$ column (third floor to last floor), $200 \mathrm{~mm} \times 500 \mathrm{~mm}$ (typical beam section), $150 \mathrm{~mm}$ (slab thickness) and $200 \mathrm{~mm}$ (wall thickness). This paper used 3D finite model of the building. The software package SAP2000, developed by Computer \& Structures Inc. [10], was utilized for this purpose. Beams and columns are modelled with frame element while shearwall and slabs are modelled with shell element (see Fig. 2).
For the given framed structures, the following representative columns were analyzed and compared $\mathrm{C} 1, \mathrm{C} 3, \mathrm{C} 5, \mathrm{C} 6$ and $\mathrm{C} 8$ (see Fig. 1). $\mathrm{C} 1$ and $\mathrm{C} 5$ are corner columns, $\mathrm{C} 3$ and $\mathrm{C} 6$ are side columns and $\mathrm{C} 8$ was middle (centre) column.

The sample buildings were analyzed in terms of the following: base shear, storey shear and the amount of reinforcement required in the representative columns at the ground storey. In order to determine the reinforcements needed by the representative columns the interaction diagrams provided by ACI Design Handbook was used as a reference [9].

\subsection{Seismic Parameters}

In order to compare only the codes provision the same earthquake action was considered in all the analysis, as so it 
was adopted the same design spectrum (from NSCP design code).

The RC frame structure has a standard occupancy with the following site characteristics: stiff soil with a shear wave velocity of $300 \mathrm{~m} / \mathrm{sec}$, the nearest seismic source is within 5 $\mathrm{km}$, and the fault is capable of producing a large magnitude event with high rate of seismic activity [3]. The site characteristics and seismic parameters as per NSCP 2010 are given in Table 2. The seismic coefficients are $\mathrm{Ca}=0.53$ and $\mathrm{Cv}=$ 1.02. A $5 \%$ elastic damping was assumed.

Table 2. Earthquake Parameters for Equivalent Lateral Force Method (ELFM)

\begin{tabular}{|c|c|}
\hline \multicolumn{2}{|c|}{ Seismic parameters } \\
\hline Load direction & Global X\&Y direction \\
\hline \hline Eccentricity ratio & 0.05 \\
\hline Over strength factor & $\begin{array}{c}5.5 \text { (Irregular Frame) } \\
8.5 \text { (Regular Frame) }\end{array}$ \\
\hline Seismic coefficients & Soil Profile (SD) / Seismic Zone Factor $(0.40)$ \\
\hline Near source factor & Seismic Source Type (A) / Distance $(5 \mathrm{~km})$ \\
\hline Importance factor (I) & 1.0 \\
\hline
\end{tabular}

\subsection{Load Combinations}

The different load combinations for 3D structural analysis considered in each code, as shown in Table 3. From the load combinations given, EC8 $[11,12]$ considered the effects of earthquake forces in two directions.

\section{RESULTS}

\subsection{Base Shear}

A comparison of design base shear is one of the simplest ways to compare the final result. Two types of RC structures have been considered: $\mathrm{RC}$ moment resisting framed building (regular) and frame shear wall building (irregular). An office building (Fig. 1) plan has been considered for all computations.
The maximum base shear using RSA and ELFM for each case for the regular and irregular buildings was obtained using SAP2000. The results are shown in Fig. (3), the maximum base shears from NSCP 2010, EC8 and 2009 IBC are compared and analyzed. The load combinations in Table 3 for each code were also utilised in the model. The results are plotted in the $\mathrm{X}$ and $\mathrm{Y}$ directions. And the following were observed:

For 4-storey regular building as shown in Fig. (3), the design base shear in the X-direction decreases by $29 \%$ from equivalent lateral force method to response spectrum analysis.

For 4-storey irregular building as shown in Fig. (3), the design base shear in the X-direction decreases by $2 \%$ (very small difference) from equivalent lateral force method to response spectrum analysis. The same observations were made in the other directions. Based form the results, it clearly shows that regular structures design using the equivalent lateral force method provided a safe design as compared with response spectrum analysis for the three codes.

\subsection{Storey Shear Profile}

Plots of the storey shear profile versus storey height are made for all buildings and are superimposed on the same graph. The results are presented in Fig. (4). And the following were observed:

For 4-storey regular building as shown in Fig. (4), the storey shear in the X-directions increases by $28 \%$ from response spectrum analysis to equivalent lateral force method.

For 4-storey irregular building, as shown in Fig. (4), a 2 $\%$ (negligible value) increase of storey shear from equivalent lateral force method to response spectrum analysis in the $\mathrm{X}$-direction.

The same result was observed in the Y-directions. This is consistent with the results obtained in the design maximum base shear both in the $\mathrm{X}$ and $\mathrm{Y}$ directions.

\subsection{Axial Load- Moment Interaction Diagrams}

In this section are analyzed the column axial load - bending moment interaction diagrams for columns $\mathrm{C} 1, \mathrm{C} 3, \mathrm{C} 5$, $\mathrm{C} 6$ and $\mathrm{C} 8$. The equations used to generate data for plotting

Table 3. Load Combinations

\begin{tabular}{|c|c|c|c|}
\hline Case & NSCP 2010 & EC8 & 2009 IBC \\
\hline \hline DL* & $1.4 \mathrm{DL}$ & $1.4 \mathrm{DL}$ \\
\hline \multirow{2}{*}{ DL\&LL* } & $1.2 \mathrm{DL}+1.6 \mathrm{LL}$ & - & $1.2 \mathrm{DL}+1.6 \mathrm{LL}$ \\
\hline \multirow{2}{*}{ DL\&EQ* } & $0.9 \mathrm{DL} \pm 1.0 \mathrm{EQX}$ & - & $0.9 \mathrm{DL} \pm 1.0 \mathrm{EQX}$ \\
\cline { 2 - 4 } & $0.9 \mathrm{DL} \pm 1.0 \mathrm{EQY}$ & $1.0 \mathrm{DL}+0.3 \mathrm{LL} \pm 1.0 \mathrm{EQX}$ & $1.2 \mathrm{DL}+1.0 \mathrm{LL} \pm 1.0 \mathrm{EQX}$ \\
\hline \multirow{3}{*}{ DL,LL\&EQ* } & $1.2 \mathrm{DL}+1.0 \mathrm{LL} \pm 1.0 \mathrm{EQX}$ & $1.0 \mathrm{DL}+0.3 \mathrm{LL} \pm 1.0 \mathrm{EQY}$ & $1.2 \mathrm{DL}+1.0 \mathrm{LL} \pm 1.0 \mathrm{EQY}$ \\
\cline { 2 - 4 } & $1.2 \mathrm{DL}+1.0 \mathrm{LL} \pm 1.0 \mathrm{EQY}$ & $1.0 \mathrm{DL}+0.3 \mathrm{LL} \pm 1.0 \mathrm{EQX} \pm 1 / 3 \mathrm{EQY}$ & - \\
\cline { 2 - 4 } & - & $1.0 \mathrm{DL}+0.3 \mathrm{LL} \pm 1.0 \mathrm{EQY} \pm 1 / 3 \mathrm{EQX}$ & - \\
\hline
\end{tabular}

Note* DL (Dead-Load), LL (Live-Load) and EQ (EarthQuake load in X and Y directions respectively) 


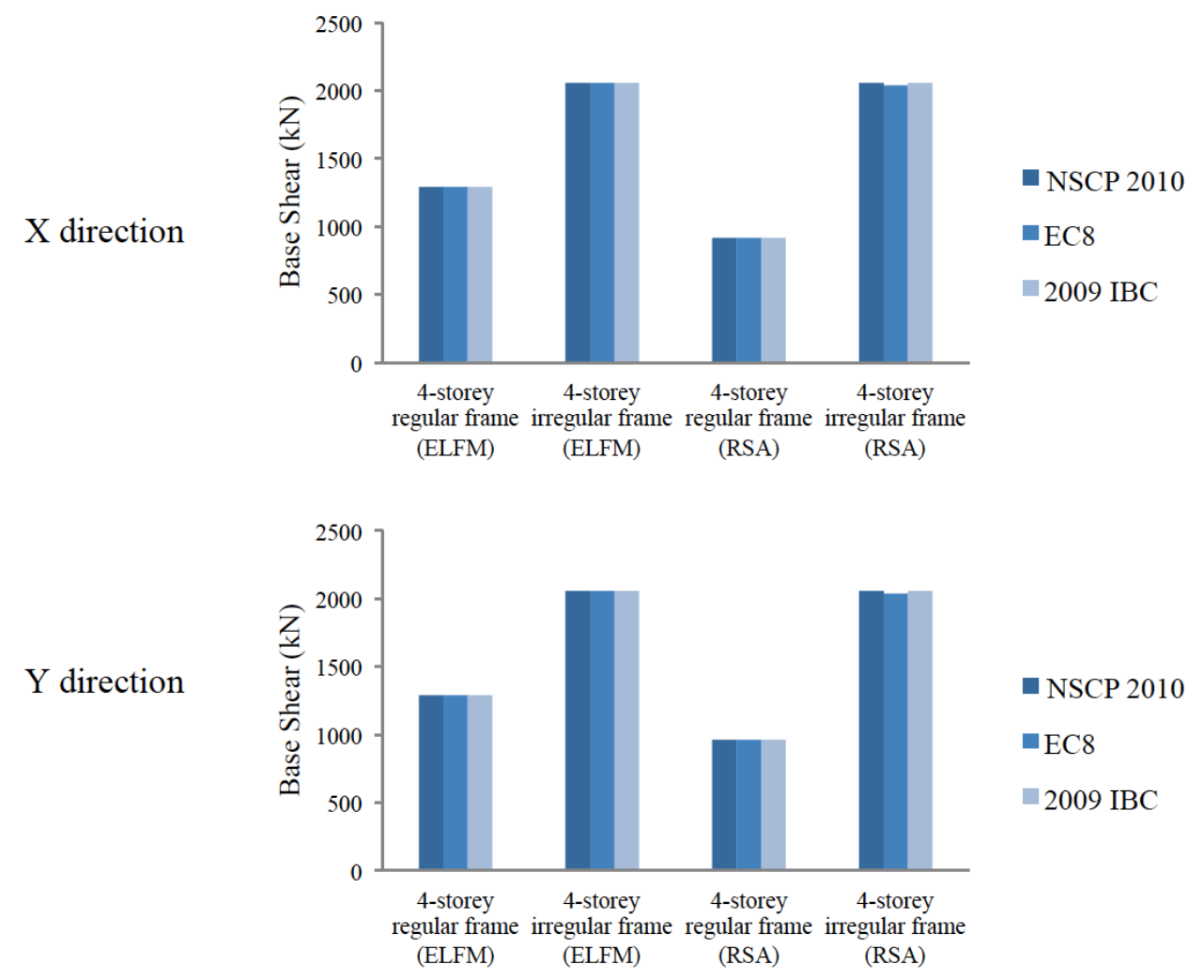

Fig. (3). Maximum base shear.
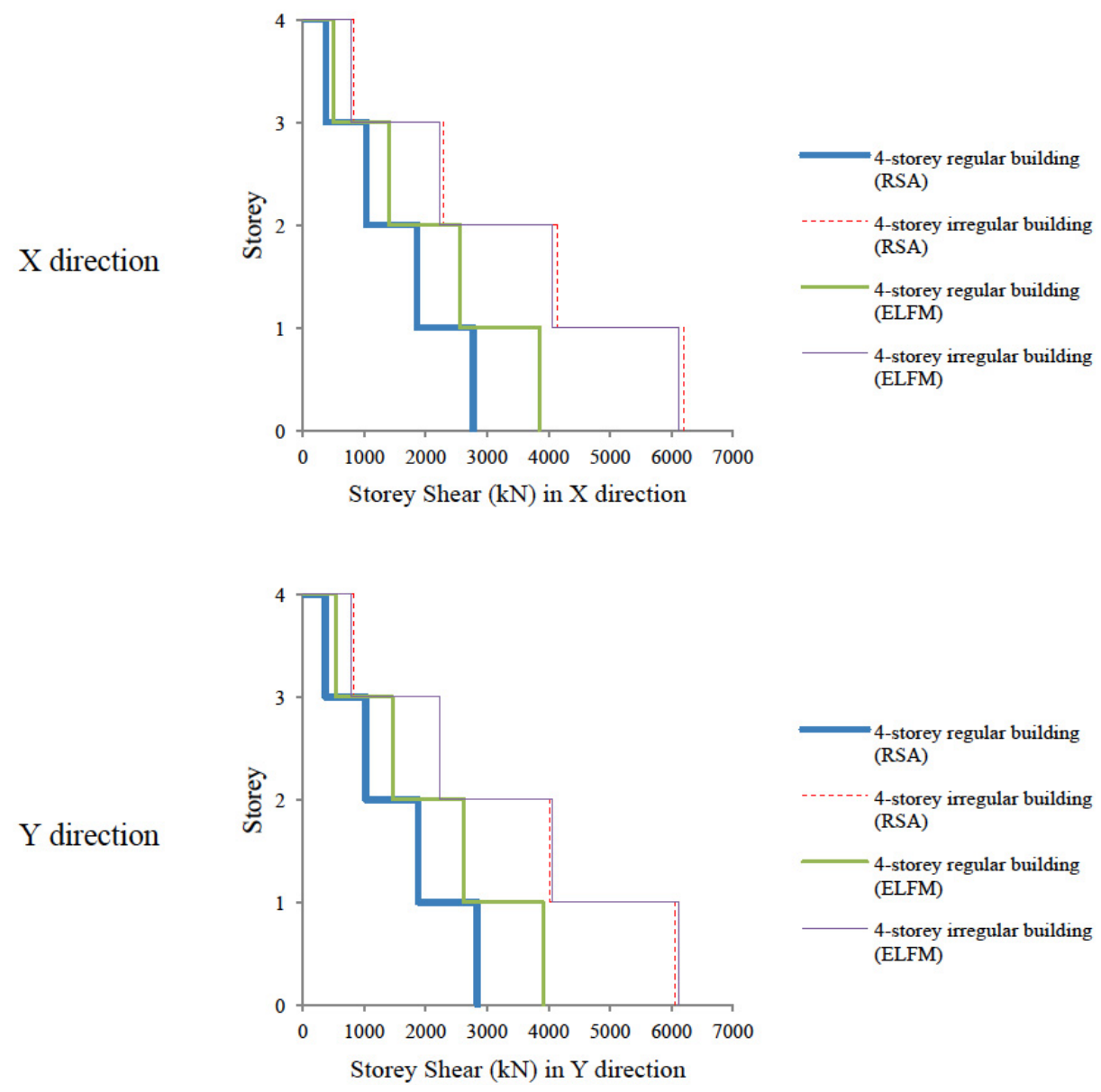

Fig. (4). Storey shear the for 4-storey RC frame. 
the interaction diagrams were developed by ACI Special Publication SP-73. The original interaction diagrams that were contained in SP-7 were subsequently published in Special Publication SP-17A5 [9]. In plot, the vertical axis represents the normalized axial load capacity of the section, and the horizontal axis represents the nominal bending moment capacity of the section. The plots are in the non-dimensional form, so that the interaction diagrams could be analyzed independently of the unit system [9]. Furthermore, the representative columns were taken in the ground floor of each building. The results are shown in Fig. (5) and Fig. (6) for regular and irregular frame respectively.

\#

4-storey regular frame (RSA)

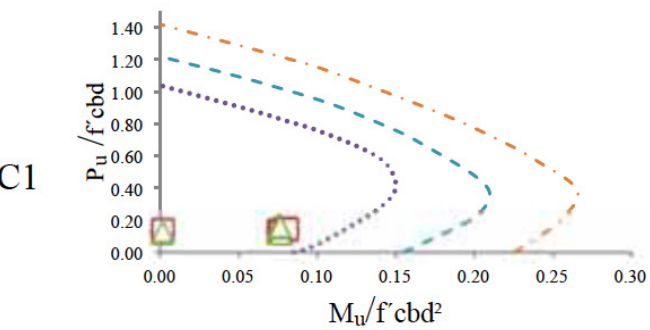

C3

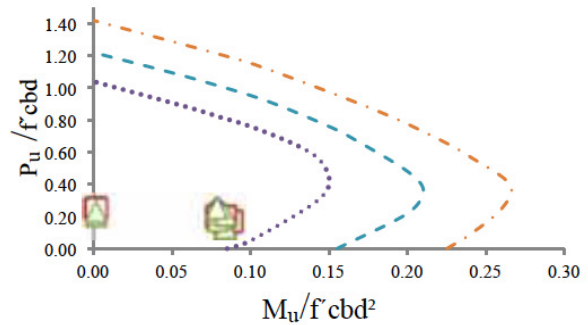

C5

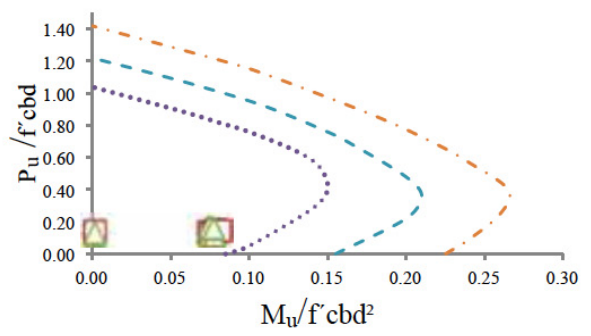

C6
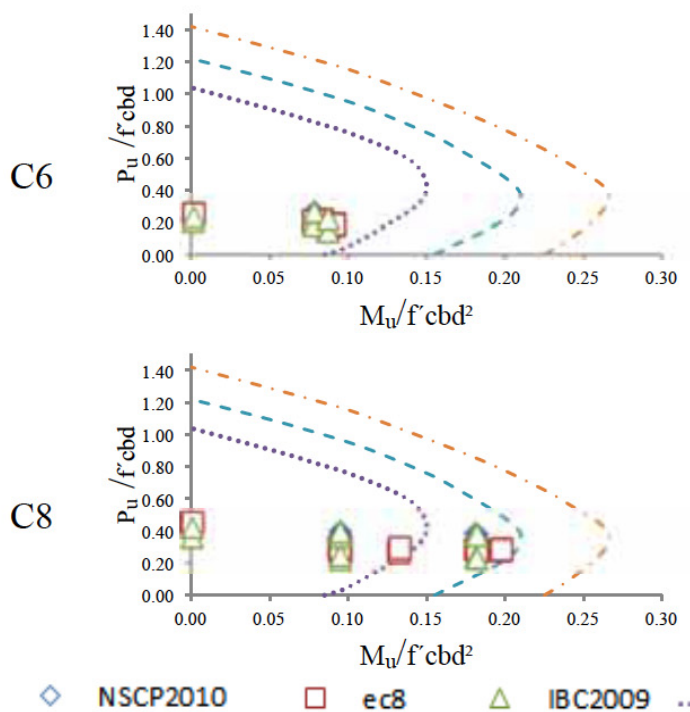

The interaction diagrams for regular building using the response spectrum analysis are shown in Fig. (5). It can be seen that $\mathrm{C} 1, \mathrm{C} 3, \mathrm{C} 5$ and $\mathrm{C} 6$ require a steel reinforcement ratio of less than $1 \%$ and $\mathrm{C} 8$ require a $2 \%$ steel reinforcement ratio. The result is consistent with the three standards, NSCP 2010, EC8 and 2009 IBC. The three standards also require a $1 \%$ steel reinforcement ratio in reinforced concrete section for column as a minimum $[3,11,13]$.

The interaction diagrams for regular building using the equivalent lateral force method are shown in Fig. (5) for each storey. It is clearly shown that all the columns, C1, C3, C5, $\mathrm{C} 6$ and $\mathrm{C} 7$ require a $1 \%$ steel reinforcement ratio as required

\section{4-storey regular frame (ELFM)}
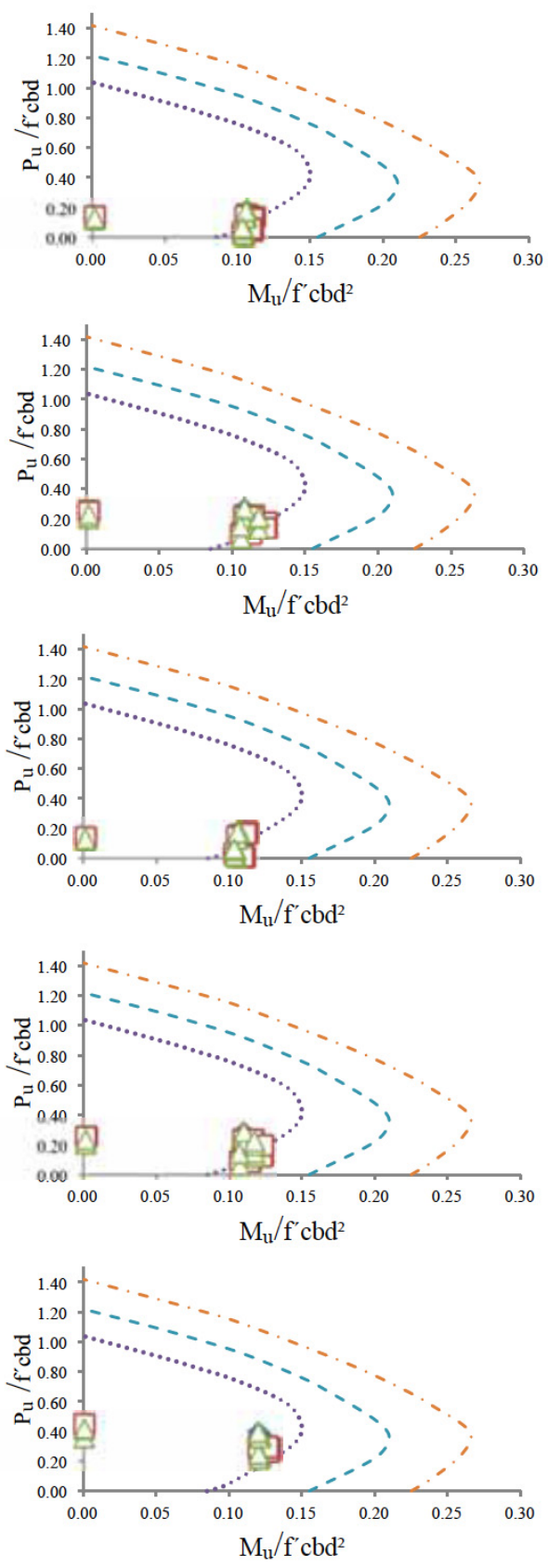

$1 \%$

Fig. (5). Interaction diagrams for $\mathrm{C} 1, \mathrm{C} 3, \mathrm{C} 5, \mathrm{C} 6$ and $\mathrm{C} 8$ for 4-storey regular $\mathrm{RC}$ frame for each storey. 


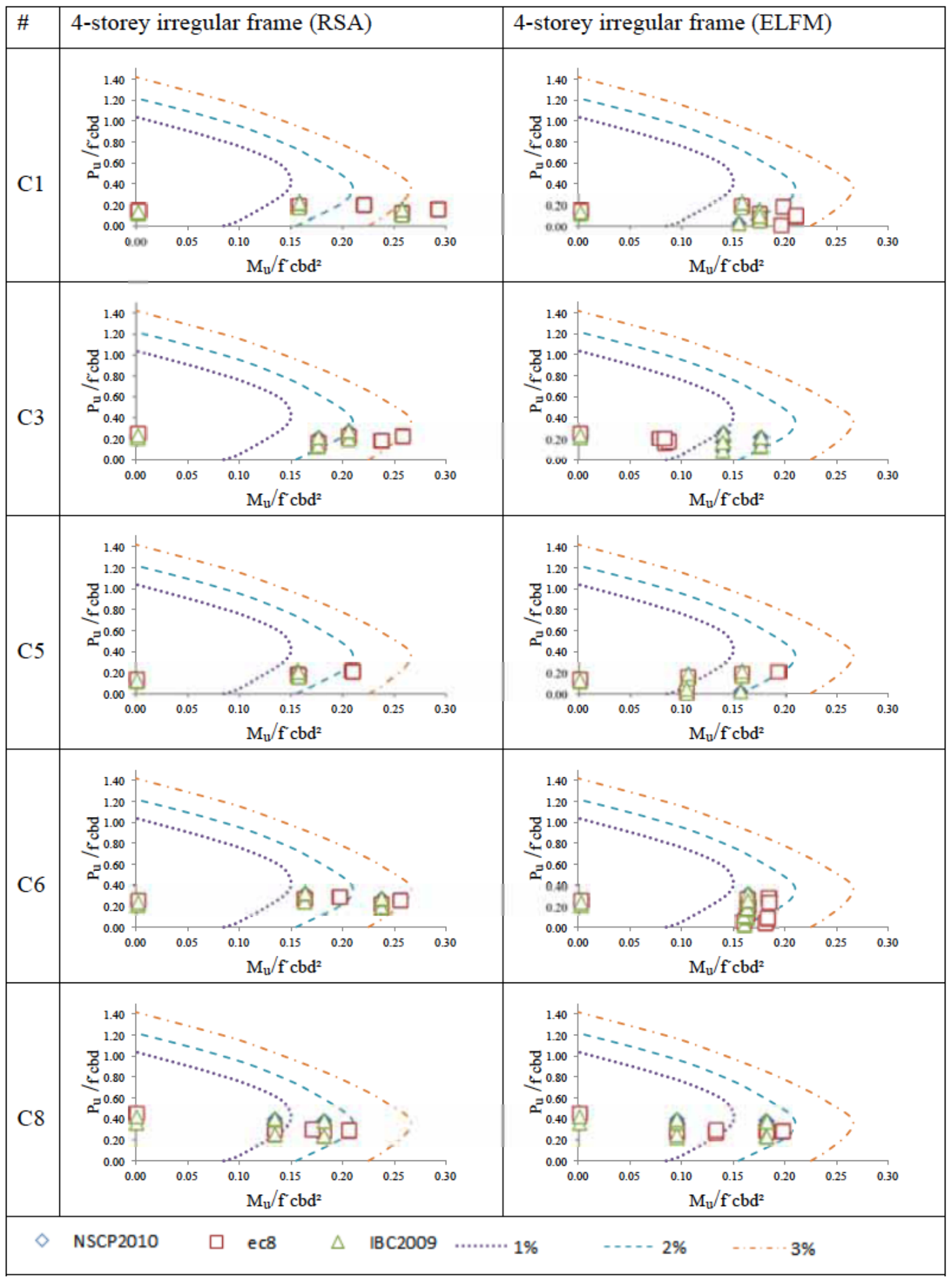

Fig. (6). Interaction diagrams for C1, C3, C5, C6 and C8 for 4-storey irregular RC frame for each storey.

by the three seismic codes. Based form these preliminary results, the building design using the ELFM are safer as compared with RSA. It can also be noted that the different load combinations given in the three seismic codes provided a negligible influence on the results.

The interaction diagrams for 4-storey irregular building using the response spectrum analysis are shown in Fig. (6) for each storey. The results of steel reinforcement ratio in the representative columns are shown in Table 4 with the corresponding seismic design codes respectively, NSCP 2010, EC8 and 2009 IBC. It can be seen in the table, that C6 and $\mathrm{C} 5$ have the minimum and maximum difference in the steel ratio. $\mathrm{C} 1, \mathrm{C} 3$ and $\mathrm{C} 8$ have an average difference of $17 \%$. From the same table, it should be noted that EC8 required the highest steel requirement ratio of $3.8 \%$ as compared with the $1 \%$ steel ratio required by the three seismic codes 
Table 4. Steel Reinforcement Ratio Using Response Spectrum Analysis - 4-Storey Irregular RC Frame

\begin{tabular}{|c|c|c|c|c|}
\hline Column & NSCP 2010 (\%) & EC8 (\%) & 2009 IBC (\%) & Difference (\%) \\
\hline \hline C1 & 3.20 & 3.80 & 1.80 & 20 \\
\hline C3 & 1.80 & 2.20 & 2.20 & 36 \\
\hline C5 & 2.20 & 3.00 & 2.80 & 19 \\
\hline C6 & 2.80 & 3.00 & 1.80 & 11 \\
\hline
\end{tabular}

Table 5. Steel Reinforcement Ratio Using Equivalent Lateral Force Method - 4-Storey Irregular RC Frame

\begin{tabular}{|c|c|c|c|c|}
\hline Column & NSCP 2010 (\%) & EC8 (\%) & 2009 IBC (\%) & Difference (\%) \\
\hline \hline C1 & 2.00 & 2.40 & 2.00 & 20 \\
\hline C3 & 2.00 & 2.20 & 2.00 & 10 \\
\hline C5 & 2.00 & 1.00 & 1.80 & 22 \\
\hline C6 & 1.80 & 2.20 & 1.80 & 11 \\
\hline
\end{tabular}

as the minimum steel ratio. From the global analysis it is clear that EC8 require more steel ratio when compared with other design codes.

The interaction diagrams for 4-storey irregular building using the equivalent lateral force method are shown in Fig. (6). The results of steel reinforcement ratio in the representative columns are shown in Table 5 with the corresponding seismic design codes respectively, NSCP 2010, EC8 and 2009 IBC $8[3,10,12]$.

It can be seen in the table, that $\mathrm{C} 3$ and $\mathrm{C} 5$ have the minimum and maximum difference in the steel ratio. $\mathrm{C} 1, \mathrm{C} 6$ and $\mathrm{C} 8$ have an average difference of $18 \%$ steel reinforcement ratio. From the same table, it should be noted that EC8 required the highest steel requirement ratio of $2.4 \%$ as compared with the $1 \%$ steel ratio required by the three seismic codes.

Furthermore, EC8 considered the effects of earthquake load in 2 directions and this was not considered in NSCP 2010 and 2009 IBC, and this resulted to an increase in the reinforcement ratio in all representative columns especially on the corner column. This effect is more pronounced in the irregular frame.

In fact the ductility is significantly affected in columns subjected to biaxial load paths, and the consideration of the axial load $v s$ biaxial bending moment interaction. This effect can be partially considered with the earthquake load in 2 directions, especially in corner columns, subject to higher bending moment and lower values of axial loads [5].

\section{CONCLUSIONS}

A comparison of NSCP 2010, EC8 and 2009 IBC standard has been presented focusing on the building base shear, storey shear profile and column axial load - bending moment interaction diagrams. The structural model for the RC frames was analyzed in SAP2000. The results for maximum base shear, storey shear, axial loads and bending moments were compared and obtained using the NSCP2010 response spectrum function and the corresponding seismic parameters. It was evident from the results that EC8 was found to be conservative as compared to NSCP 2010 and 2009 IBC. The majority of the representative columns require more reinforcements as per EC8 when compared with NSCP 2010 and 2009 IBC. It can also be noted that in the load combination cases, EC8 considered the effects of earthquake actions in both directions which is not considered in the NSCP 2010 and 2009 IBC standards.

Therefore, the RC buildings designed using the EC8 are expected to have larger reinforcement requirements than the buildings designed using the NSCP 2010 and 2009 IBC. The results presented were applicable to residential buildings with standard occupancy and for typical loading conditions. The study presented in this paper increases the understanding of an important earthquake engineering issues concerning the different seismic design codes.

Furthermore, to generalize the results obtained in this study, an analysis on substantial number of structures with different irregularities, characteristics and storey levels should be made.

\section{CONFLICT OF INTEREST}

The author(s) confirm that this article content has no conflicts of interest.

\section{ACKNOWLEDGEMENT}

The authors gratefully acknowledge the funding provided by the Portuguese Foundation for Science and Technology 
("FCT - Fundação para a Ciência e Tecnologia"), Portugal, through the research project with reference PTDC/ECM/102221/2008.

\section{REFERENCES}

[1] H. Varum, Seismic assessment, strengthening and repair of existing buildings, PhD Thesis, University of Aveiro (UA), Portugal, pp. 508, 2003.

[2] B. Taranath, Reinforced Concrete Design of Tall Buildings. USA: Taylor and Francis Group LLC 2010.

[3] ASEP Inc., National Structural Code of the Philippines (C101-10) Buildings, Towers and Other Vertical Structures. Philippines: ASEP Inc.; 2010 pp. 758, 2010.

[4] Eurocodes building the future. http://eurocodes.jrc.ec.europa.eu/home.php [Access data: October 15 ${ }^{\text {th }}, 2013$ ].

[5] H. Rodrigues, A. Arêde, H. Varum, and A. Costa, "Experimental evaluation of rectangular reinforced concrete column behaviour under biaxial cyclic loading", Earthquake Engineering \& Structural Dynamics, vol. 42, no. 2, pp. 239-259, 2012.
[6] H. Rodrigues, H. Varum, and A. Costa, "Simplified macro-model for infill masonry panels", Journal of Earthquake Engineering vol. 2010, pp. 390-416, 2010.

[7] M. Green, Building Codes for Existing and Historic Buildings. USA: John Wiley and Sons Inc, 2012, pp. 19-37, 2012.

[8] International Code Council, Inc., International Building Code. Falls Church, VA, USA: ICC Inc.; 2009, pp. 303-345, 2009.

[9] ACI SP-17(09). ACI Design Handbook. American Concrete Institute. Michigan: ACI International, pp. 1-26, 2009.

[10] Computer \& Structures Inc. Structural Analysis Programs, SAP2000, Computer Software Package. California: CSI Inc 2005.

[11] European Standard. Eurocode 2: Design of concrete structures Part 1-1: General rules and rules for buildings, Commission of the European Communities. Brussels: European Committee for Standardization, pp. 226, 2004

[12] European Standard. Eurocode 8: Design of concrete structures for earthquake resistance - Part 1-1: General rules and rules for buildings, Commission of the European Communities. Brussels: European Committee for Standardization 2000, pp. 229.

[13] ACI 318-08. Building Code Requirements for Structural Concrete (318-08) and commentary (318R-08). American Concrete Institute. Michigan: ACI International, 2008, pp. 465.

Received: October 18, 2013

Revised: December 17, 2013

Accepted: December 17,2013

(C) Landingin et al.; Licensee Bentham Open.

This is an open access article licensed under the terms of the Creative Commons Attribution Non-Commercial License (http://creativecommons.org/licenses/by-nc/3.0/) which permits unrestricted, non-commercial use, distribution and reproduction in any medium, provided the work is properly cited. 